\title{
Evaluation of scented geranium accessions for morphological and yield attributes in southern Indian conditions
}

\author{
B.S. Harish ${ }^{1}$, V. P. SINGH*, T. Vasant Kumar ${ }^{2}$, Y.C. Vishwanath and H.T. Sakhubai \\ College of Horticulture, University of Horticultural Sciences, BAGALKOT (KARNATAKA) INDIA \\ (Email : vpsingh.neev@gmail.com)
}

\begin{abstract}
Scented geranium (Pelargonium spp.: Geraniaceae) is an important, high value aromatic crop of South African origin. The oil of geranium is obtained by steam distillation of tender plant parts. More than 120 constituents are identified in the oil. Due to high demand and price for the oil, an excellent potential exists for increasing cultivated area in India. An attempt was made to evaluate and characterize the available accessions of scented geranium based on their morphology and yield attributes. There were seven treatments and four replications. PG-12 recorded maximum plant height $(53.45 \mathrm{~cm})$, PG-1 recorded maximum plant spread $\left(6706.43 \mathrm{~cm}^{2}\right)$, PG-12 registered maximum number of leaves (469.20), PG-11 recorded the highest $(12.35 \mathrm{~mm})$ stem diameter. Flowering was observed in the accessions PG-1, PG-8, PG-10, KB and CIMAP though the extent varied widely. KB recorded the maximum herb yield per plant, per plot and per hectare $(0.69 \mathrm{~kg}, 13.90 \mathrm{~kg}$ and $19.30 \mathrm{t}$, respectively). PG- 8 registered the maximum oil content $(0.437 \%), \mathrm{KB}$ recorded the maximum essential oil $(2.07 \mathrm{ml}, 41.43 \mathrm{ml}$ and 57.53 1, respectively) per plant, per plot and per hectare oil yield. So, KB and PG-8 were found best among all for their essential oil yield and quality.
\end{abstract}

Key Words : Geranium, Accessions, Evaluation

View Point Article : Harish, B.S., SINGH, V. P., Kumar, T. Vasant, Vishwanath, Y. C. and Sakhubai, H.T. (2018). Evaluation of scented geranium accessions for morphological and yield attributes in southern Indian conditions. Internat. J. agric. Sci., 14 (1) : 65-69, DOI: 10.15740/HAS/IJAS/14.1/65-69.

Article History : Received : 04.10.2017; Revised : 08.11.2017; Accepted : 21.11.2017

\footnotetext{
* Author for correspondence:

${ }^{1}$ College of Horticulture, MYSORE (KARNATAKA) INDIA

${ }^{2}$ Indian Institute Of Horticultural Research, BENGALURU (KARNATAKA) INDIA
} 